\title{
A STUDY OF THE PHYSICO-MECHANICAL PROPERTIES IN SHORT BLEACHING SEQUENCES
}

\author{
Ana Paula Almeida Ferraz ${ }^{2 *}$ and Gustavo Ventorim ${ }^{3}$
}

\footnotetext{
${ }^{1}$ Received on 10.07.2018 accepted for publication on 14.09.2018.

${ }^{2}$ Universidade Estadual Paulista Júlio de Mesquita Filho, Programa de Pós-Graduação em Engenharia Mecanica, Guaratinguetá, SP - Brasil. E-mail: <ana.almeida.ferraz@gmail.com>.

${ }^{3}$ Universidade Estadual Paulista, Departamento de Engenharia Industrial Madeireira,Itapeva, SP - Brasil . E-mail: <gustavo.ventorim@unesp.br>.

*Corresponding author.
}

\begin{abstract}
The kraft pulp of Eucalyptus spp. is relatively easy to be bleached. Therefore, studies have been carried out to reduce the number of stages of bleaching in the plant and minimize process costs. The present work aimed to evaluate the use of two short bleaching sequences in the physico-mechanical properties of cellulosic pulp as well as to compare these values to the ones obtained by usual bleaching sequences. The four bleaching sequences were ECF (elemental chlorine free), $\mathrm{D}_{0}(\mathrm{E}+\mathrm{P}) \mathrm{D}_{1} \mathrm{P}, \mathrm{A}_{\mathrm{HT}} \mathrm{D}_{0}(\mathrm{E}+\mathrm{P}) \mathrm{D}_{1} \mathrm{P}$, and $\mathrm{A}_{\mathrm{HT}} \mathrm{DP}$ and $\mathrm{A}_{\mathrm{HT}} \mathrm{D}(\mathrm{PO})$. For each bleaching sequence the brightness, brightness reversion and total cost of reagents were evaluated. Physical and mechanical analyses were performed according to the methodologies of the Technical Association of the Pulp and Paper Industry (TAPPI, 2002). The $\mathrm{A}_{\mathrm{HT}} \mathrm{D}$ (PO) sequence showed higher brightness, less brightness reversion, lower total cost and better smoothness compared to the reference sequences. However, it had a lower tear index and a lower compression index. The $\mathrm{A}_{\mathrm{HT}} \mathrm{DP}$ sequence did not reach target brightness, however, it presented brightness reversion and lower total cost than the reference sequences. The $A_{\mathrm{HT}} \mathrm{DP}$ sequences showed high compression and smoothness, but presented a low compression index.
\end{abstract}

Keywords: Cellulose, Eucalyptus, Short sequences, Elemental chlorine free bleaching.

\section{ESTUDO DAS PROPRIEDADES FÍSICO-MECÂNICAS EM SEQUÊECIAS CURTAS DE BRANQUEAMENTO}

\begin{abstract}
RESUMO - A polpa kraft de Eucalyptus spp. é relativamente fácil de ser branqueada. Portanto estudos têm sido feitos a fim de diminuir o número de estágios de branqueamento na planta, minimizando assim, custos do processo. O presente trabalho teve por objetivo avaliar a utilização de duas sequências curtas de branqueamento, nas propriedades físico-mecânicas da polpa celulósica, bem como comparar os valores aos valores obtidos por sequências usuais de branqueamento. Foram estudadas quatro sequências de branqueamento ECF (livre de cloro elementar), $D_{0}(E+P) D_{I} P, A_{H T} D_{0}(E+P) D_{I} P, A_{H T} D P$ e $A_{H T} D(P O)$. Para cada sequência de branqueamento foram avaliadas a alvura, reversão de alvura e custo total dos reagentes. As análises físicas e mecânicas foram realizadas de acordo com as metodologias da Technical Association of the Pulp and Paper Industry (TAPPI, 2002). A sequência $A_{H T} D(P O)$ apresentou maior alvura, menor reversão de alvura, menor custo total e melhor lisura comparada às sequências referências. Entretanto apresentou menor índice de rasgo e menor índice de compressão. A sequência $A_{H T} D P$ não atingiu a alvura objetivo, porém, apresentou menor reversão de alvura e menor custo de branqueamento do que as sequências referências. A sequências $A_{H T} D P$ apresentou alto índice de compressão e lisura, porém apresentou baixo índice de rasgo.
\end{abstract}

Palavras-Chave: Celulose. Eucalipto. Sequências curtas. Branqueamento livre de cloro elementar. 


\section{INTRODUCTION}

Milagres et al. (2011) consider that the kraft pulps of Eucalyptus spp. are relatively easy to bleach because they present a higher quantity of hexenuronic acids. As a result, many studies have been done in order to decrease the number of stages of bleaching sequences and to reduce the costs of the process.

Setting up a modern large (3,000 tons/day) bleach plant with five stages (including the stage of oxygen delignification) for the pulp of Eucalyptus spp. requires investments of approximately 40 to 50 million dollars (Milanez et al., 2008; Milagres et al., 2011). Due to this considerable cost, studies aiming to minimize the costs of implementing new bleaching sequences have been gaining recognition. One possible option in this case is reducing the number of bleaching stages, in other words, the preference for short sequences, taking into account that each stage incurred costs of approximately 10 million dollars (Milanez et al., 2008).

Given the fact that the modern processes of pulping and washing are providing increasingly brighter pulps, there is a growing tendency for reducing the number of bleaching stages. Colodette and Santos (2015) argue that nowadays three-stage sequences provide effective results concerning brightness since they are considered sufficient to bleach the kraft pulp of the eucalyptus that was previously delignified with oxygen.

Thus, the objective of this study was to evaluate the physico-mechanical properties of two short bleaching sequences.

\section{MATERIALAND METHODS}

In this study, the pre-delignified industrial pulp of eucalyptus was used with oxygen. The initial characteristics of the pulp were: $60.4 \%$ ISO brightness and kappa number 9.8.

Two reference bleaching sequence has been used, $\mathrm{D}_{0}(\mathrm{E}+\mathrm{P}) \mathrm{D}_{1} \mathrm{P}$ and $\mathrm{A}_{\mathrm{HT}} \mathrm{D}_{0}(\mathrm{E}+\mathrm{P}) \mathrm{D}_{1} \mathrm{P}$, and other two bleaching sequences, $\mathrm{A}_{\mathrm{HT}} \mathrm{DP}$ and $\mathrm{A}_{\mathrm{HT}} \mathrm{D}(\mathrm{PO})$, were used as alternatives (short sequences). The Conditions are presented in Table 1.

Bleaching in non-pressurized stages was performed in polyethylene bags with representative samples of the pulp. Bleach liquor was added to the pulp at room temperature. Samples of the residual pulp liquor were extracted in the end of reaction, in order to conduct the $\mathrm{pH}$ analysis. The pulp was washed using a washing factor of $9 \mathrm{~m}^{3} / \mathrm{t}$ dry basis of clean water.

The pressurized hydrogen peroxide (PO) stage was performed in an autoclave system, with four individual stainless steel reactors, each with a capacity of 1.5 liters and temperature and pressure settings. For each capsule, $100 \mathrm{~g}$ dry basis of pulp was mixed with a bleach liquor, which is comprised by water, $\mathrm{NaOH}$ and $\mathrm{H}_{2} \mathrm{O}_{2}$. After the set temperature was reached, oxygen was applied to keep $500 \mathrm{kPa}$ pressure. At the end of the stage, the pressure was relieved. Samples of the residual pulp liquor were extracted in order to conduct the $\mathrm{pH}$ analysis. The pulp was washed using a washing factor of $9 \mathrm{~m}^{3} / \mathrm{t}$ dry basis of clean water.

The bleached pulps were refined in a PFI mill at four levels: 0, 1000, 2000 and 3000 revolutions.

Table 1 - General Bleaching Conditions.

Tabela 1 - Condições gerais do processo de branqueamento.

\begin{tabular}{|c|c|c|c|c|c|c|c|}
\hline \multirow{2}{*}{ Conditions } & \multicolumn{6}{|c|}{ Bleaching Stages } & \multirow[b]{2}{*}{$\mathrm{PO}$} \\
\hline & $\mathrm{A}_{\mathrm{HT}}$ & $\mathrm{D}_{0}$ & $(\mathrm{E}+\mathrm{P})$ & $\mathrm{D}_{1}$ & $\mathrm{D}$ & $\mathrm{P}$ & \\
\hline Consistency (\%) & 10 & 10 & 10 & 10 & 10 & 10 & 10 \\
\hline Time (min) & 120 & 30 & 60 & 180 & 120 & 120 & 120 \\
\hline Temperature $\left({ }^{\circ} \mathrm{C}\right)$ & 95 & 60 & 70 & 70 & 70 & 95 & 95 \\
\hline Pressure $(\mathrm{kPa})$ & - & - & - & - & - & - & 500 \\
\hline Final $\mathrm{pH}$ & 3 & 3 & 10.5 & 3.8 & 6 & 10.5 & 10.5 \\
\hline $\mathrm{NaOH}, \mathrm{kg} / \mathrm{odt}^{*}$ & - & - & 8 & - & - & 6 & 8 \\
\hline $\mathrm{H}_{2} \mathrm{SO}_{4}, \mathrm{~kg} / \mathrm{odt}^{*}$ & Otim. & Otim. & - & - & - & - & - \\
\hline $\mathrm{O}_{2}, \mathrm{~kg} / \mathrm{odt}^{*}$ & - & - & - & - & - & - & 20 \\
\hline $\mathrm{ClO}_{2}, \mathrm{~kg} / \mathrm{odt} *$ as $\mathrm{Cl}_{2}$ & - & $\mathrm{FK}^{1}=0.16$ & - & 8 & 20 & - & - \\
\hline $\mathrm{H}_{2} \mathrm{O}_{2}, \mathrm{~kg} / \mathrm{odt}^{*}$ & - & - & 3 & - & - & 6 & 3 \\
\hline
\end{tabular}

Revista Árvore. 2018;42(5):e420505 
Compression resistance, smoothness, and tear resistance were performed on handsheets with grammage of 60 g. $\mathrm{m}^{-2}$ acoording TAPPI 826 pm-92, TAPPI $479 \mathrm{~cm}-99$ and TAPPI 414 om-98. The analyses of brightness and brightness reversion, according to the methods TAPPI 525 om 92 and TAPPI 525 om- 92 ( $\left.4 \mathrm{~h}, 105 \pm 3{ }^{\circ} \mathrm{C}, 0 \% \mathrm{UR}\right)$.

The total costs of bleaching were calculated taking into account the quantity of reagents used in each stage (kg/odt) and the price of each reagent used (US\$/ $\mathrm{kg}$ ). For this calculation, were used chemicals prices (US $\$ / \mathrm{kg}$ of product) according Favaro et al., (2014): chlorine dioxide $=1.0$; hydrogen peroxide $=0.85$; oxygen $=0.10$; sodium hydroxide $=0.50$; sulfuric acid $=0.08$.

In order to evaluate the statistical difference between the average brightness and brightness reversion, the Test Method T was employed. In order to evaluate the differences between the values of compression indexes, smoothness, and tear indexes, the analysis of variance (ANOVA) was adopted. Tukey's multiple comparison tests were conducted among the bleaching sequences in order to find which of these sequences presented the most significant differences. The significance level adopted in the statistical analyses was $5 \%$.

\section{RESULTS}

\section{Brightness}

The results of the bleaching sequences are presented below with the total costs of bleaching.

\section{Physico-mechanical Test}

In order to evaluate the impact of the different bleaching sequences, three tests were performed: compression resistance, smoothness, and tear resistance. Figure 1 describes the compression indexes found for each bleaching sequence.

Figure 2 describes the smoothness found for each bleaching sequence.

Figure 3 describes the tear indexes found for each bleaching sequence

\section{DISCUSSION}

\section{Brightness}

Table 2 shows that the sequence $\mathrm{A}_{\mathrm{HT}} \mathrm{D}(\mathrm{PO})$ reached the same brightness compared with reference ones.
Table 2 - Pulp characteristics and total bleaching costs. Tabela 2 - Características das polpas e custos totais do branqueamento.

\begin{tabular}{|c|c|c|c|c|}
\hline \multirow[b]{2}{*}{ Results } & \multicolumn{4}{|c|}{ Sequences } \\
\hline & $\begin{array}{c}\mathrm{D}_{0}(\mathrm{E}+\mathrm{P}) \\
\mathrm{D}_{1} \mathrm{P}\end{array}$ & $\begin{array}{c}\mathrm{A}_{\mathrm{HT}} \mathrm{D}_{0} \\
(\mathrm{E}+\mathrm{P}) \mathrm{D}_{1} \mathrm{P}\end{array}$ & $\mathrm{A}_{\mathrm{HT}} \mathrm{DP}$ & $\begin{array}{l}\mathrm{A}_{\mathrm{HT}} \mathrm{D} \\
(\mathrm{PO})\end{array}$ \\
\hline Brightness, \%ISO & $90.1 \mathrm{a}$ & $90.3 a$ & $88.4 b$ & $90.5 \mathrm{c}$ \\
\hline $\begin{array}{l}\text { Brightness } \\
\text { Reversion, \%ISO }\end{array}$ & $2.2 \mathrm{a}$ & $1.5 \mathrm{~b}$ & $1.2 \mathrm{c}$ & $1.0 \mathrm{c}$ \\
\hline $\mathrm{ClO}_{2}$ as $\mathrm{Cl}_{2}, \mathrm{~kg} / \mathrm{odt}^{*}$ & 23.7 & 21.6 & 20 & 20 \\
\hline $\mathrm{H}_{2} \mathrm{O}_{2}, \mathrm{~kg} / \mathrm{odt} *$ & 9.0 & 9.0 & 6.0 & 3.0 \\
\hline $\mathrm{NaOH}, \mathrm{kg} / \mathrm{odt}^{*}$ & 14.0 & 14.0 & 6.0 & 8.0 \\
\hline $\mathrm{H}_{2} \mathrm{SO}_{4}, \mathrm{~kg} / \mathrm{odt}^{*}$ & 9.0 & 7.0 & 7.0 & 7.0 \\
\hline $\mathrm{O}_{2}, \mathrm{~kg} / \mathrm{odt} *$ & 0.0 & 0.0 & 0.0 & 4.0 \\
\hline $\begin{array}{l}\text { Total Cost of } \\
\text { Reagents, US\$/odt* }\end{array}$ & 38.6 & 36.8 & 28.7 & 27.3 \\
\hline
\end{tabular}

\section{odt= oven dry tonne}

* Averages followed by the same letter do not differ from one another regarding the $5 \%$ significance level according to Tukey's test.

In the $\mathrm{A}_{\mathrm{HT}} \mathrm{DP}$ sequence, the load of hydrogen peroxide used was higher than the one used in the stage of pressurized hydrogen peroxide in the $\mathrm{A}_{\mathrm{HT}} \mathrm{D}(\mathrm{PO})$ sequence,

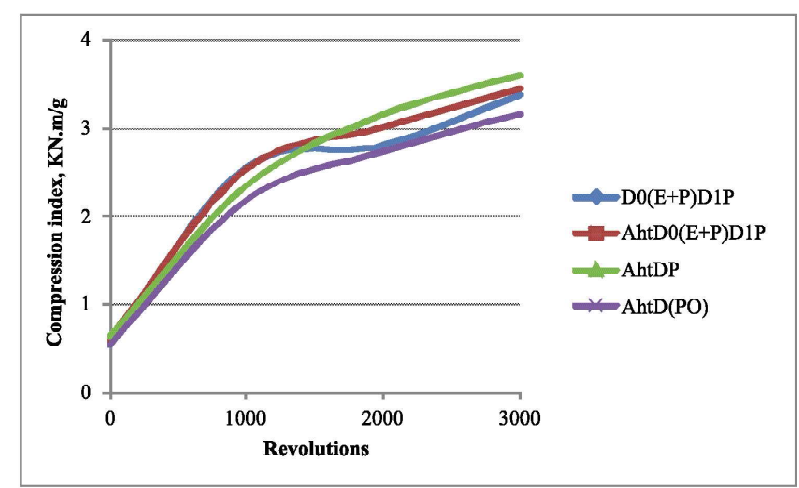

Figure 1-Compression index for each bleaching sequence. Figura 1- Índices de compressão para cada sequência de branqueamento.

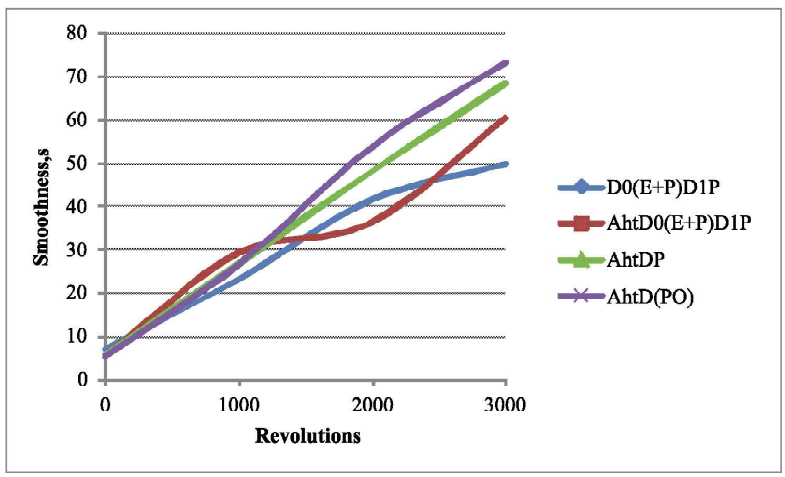

Figure 2 - Smoothness for each bleaching sequence.

Figura 2-Lisura para cada sequência de branqueamento. 


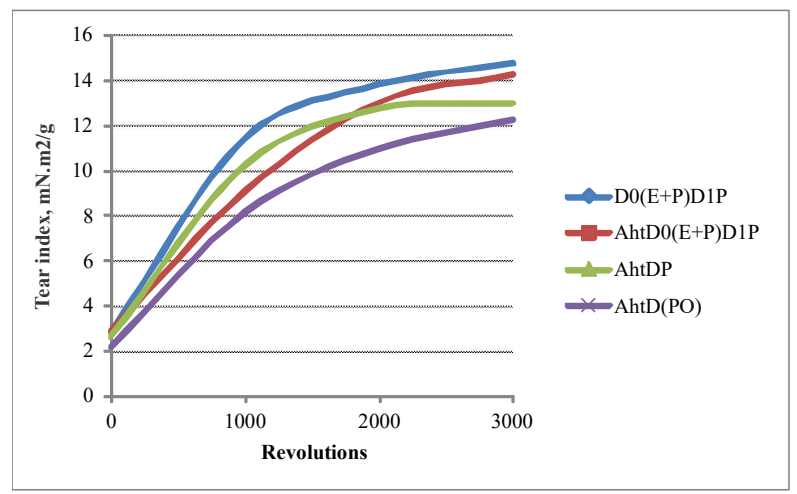

Figure 3 - Tear index for each bleaching sequence. Figura 3 - Índice de rasgo para cada sequência de branqueamento.

as shown in Table 1. Even though the load of hydrogen peroxide was higher, the $\mathrm{A}_{\mathrm{HT}} \mathrm{DP}$ sequence did not reach $90 \%$ of ISO brightness. It is believed that during the reaction the peroxide was not totally consumed. As a result, it did not perform the pulp bleaching. In order to change this condition, one alternative would be to increase the temperature or the time of retention or even both.

On the whole, the brightness reversion was lower for the sequences with the acid hydrolysis stage. The use of an acid stage enables the reduction of hexenuronic acids, which cause brightness reversion induced by metals chelated by its carboxylic group as described by Eiras et al. (2005). The brightness reversion was more effective for the short sequences, especially in the $\mathrm{A}_{\mathrm{HT}} \mathrm{D}(\mathrm{PO})$ sequence. A few authors have thought that the (PO) stage causes a high brightness stability due to its high oxidative capacity and also due to its capacity of removing the carbonyl groups that exist in the pulp. The latter are responsible for brightness reversion (Longue Júnior et al., 2015).

Considering the high cost of implementing the bleaching stages, it is essential to choose sequences with fewer stages. As observed in Table 2, the sequences with the acid stage presented lower bleaching costs. According to Ventorim et al. (2009), the stage of acid hydrolisis enables removal of the hexenuronic acids from the pulp. Such acids are known for consuming electrophilic bleaching chemicals. Thus, removing them enables saving the reagent.

The short sequences $\mathrm{A}_{\mathrm{HT}} \mathrm{DP}$ and $\mathrm{A}_{\mathrm{HT}} \mathrm{D}(\mathrm{PO})$ presented less consumption of the bleaching reagent, especially the sequence $\mathrm{A}_{\mathrm{HT}} \mathrm{D}(\mathrm{PO})$. According to Li et al. (2015), using the peroxide stage with oxygen reinforcement intensifies the bleaching of the cellulosic pulp. Therefore it helps reduce the demand of chloride dioxide significantly on the bleaching sequence.

\section{Physico-mechanical Test}

\section{Compression Indexes}

In Figure 1, it was verified that the sequence with the best compression index was the sequence $\mathrm{A}_{\mathrm{HT}} \mathrm{DP}$. The combination between the acid hydrolysis and the P final stage improved pulp refinability, enabling a higher number of bonds among the fibers and resulting in higher compression indexes. These results are agree with Favaro et al. (2014).

The $\mathrm{D}_{0}(\mathrm{E}+\mathrm{P}) \mathrm{D}_{1} \mathrm{P}$ and $\mathrm{A}_{\mathrm{HT}} \mathrm{D}_{0}(\mathrm{E}+\mathrm{P}) \mathrm{D}_{1} \mathrm{P}$ sequences had similar values for compression resistance. The sequence presenting the lowest value for the compression index was the sequence $\mathrm{A}_{\mathrm{HT}} \mathrm{D}(\mathrm{PO})$. Sequences using acid hydrolysis and pressurized hydrogen peroxide are known to be more reactive to carbohydrates (Karim et al., 2011). Pulps that were bleached by more aggressive sequences, such as the sequences using the (PO) stage, presented low mechanical properties due to the degradation of the polysaccharides in the pulp (Favaro et al., 2014).

\section{Smoothness}

Figure 2 demonstrates that the short sequences $\mathrm{A}_{\mathrm{HT}} \mathrm{DP}$ and $\mathrm{A}_{\mathrm{HT}} \mathrm{D}(\mathrm{PO})$ presented the best smoothness results compared with reference ones. The higher smoothness in these sequences occurred due to more fines generation during refining, because of high peroxide charge. In other words, the aggressive sequences (the short ones), there is a higher concentration of fines produced during the pulp refining, which fill the pores in, resulting in a very smooth handsheet (Lee et al., 2011; Nugroho, 2012).

\section{Tear Resistance}

The sequence that presented the highest tear resistance was $\mathrm{D}_{0}(\mathrm{E}+\mathrm{P}) \mathrm{D}_{1} \mathrm{P}$. This can be explained by absence of acid hydrolysis stage, which was used in other bleaching sequences. As observed by Favaro et al. (2014) the acid hydrolysis stage may cause a loss in performance derived from the degradation of carbohydrates, and consequently the potential for

Revista Árvore. 2018;42(5):e420505 
intrinsic resistance of the fibers decreases. For Jardim and Santos (2015), the chloride dioxide is a very selective reagent. As a result, it does not provide an excessive degradation of the fibers, which explains the higher tear index presented in this sequence.

The sequence that presented the lowest tear index was $\mathrm{A}_{\mathrm{HT}} \mathrm{D}(\mathrm{PO})$. When the hydrogen peroxide is used under pressure, there is an advantage of using it with a higher temperature, generating a higher brightness. However, there is also a loss of performance, since the stage of the pressurized hydrogen peroxide is more aggressive than the stage of peroxide without any oxygen. Additionally, the fact that this sequence has an acid hydrolysis stage that is also known as being aggressive to the carbohydrates caused the loss of resistance in the pulp. This factor justifies the low tear index. The hydrogen peroxide is a less selective bleaching reagent and it degrades the carbohydrates (Andrade et al., 2013). The $\mathrm{A}_{\mathrm{HT}} \mathrm{DP}$ sequence also presented a low tear index when compared to the reference sequences. However, the values were superior to those found for the $\mathrm{A}_{\mathrm{HT}} \mathrm{D}(\mathrm{PO})$ sequence. In their studies, Favaro et al. (2014) observed that the stage of pressurized hydrogen peroxide negatively affects the tear resistance of the cellulosic pulp.

\section{CONCLUSION}

For a cellulose industry to adopt a new bleaching sequence, it is necessary to carry out many studies that focus on the quality of the final product and the costs of the process. This study permitted verifying that the short sequences, compared with long and reference sequences, presented lower brightness reversion, lower final cost of the bleaching reagents and higher smoothness. However, they presented worse performance regarding the tear index.

\section{REFERENCES}

Andrade MF, Colodette JL, Oliveira FL. Evaluation of bleachability on pine and eucalyptus kraft pulps. Cerne. 2013;19(3):433-9.

Clavijo L, Cabrera MN, Kuitunen S, Liukko S, Rauhala T, Vuorinen T. Changes in a eucalyptus kraft pulp during a mild acid treatmentat high temperature. O Papel. 2012;73(4):59-64
Colodette JL, Santos VLS. Seção III: Princípios gerais do branqueamento. In: Colodette JL, Gomes FJB, editores. Branqueamento de polpa celulósica: da produção da polpa marrom ao produto acabado. Viçosa, MG: Universidade Federal de Viçosa; 2015. p.173-202.

Eiras KMM, Colodette JL, Carvalho AMML. Estudo das causas de reversão de alvura de polpas kraft de eucalipto. Cerne.

2005;11(4):354-68.

Favaro JSC, Ventorim G, Caraschi JC. Efeito de reagentes de branqueamento na classificação e refinação de polpa de eucalipto. Cerne. 2014;20(3):385-92.

Jardim CM, Santos VLS. Seção IV: Química do branqueamento. Reações químicas de branqueamento. In: Colodette JL, Gomes FJB, editores. Branqueamento de polpa celulósica: da produção da polpa marrom ao produto acabado. Viçosa, MG: Universidade Federal de Viçosa; 2015 p.216-66.

Karim MR, Islam MN, Malinen RO. Response of Eucalyptus camaldulensis and Acacia mangium kraft pulp in different ECF bleaching options. Wood Science and Technology. 2011;45(3):473-85.

Lee H, Namb WS, Sohn SD, Paik KH. Effect of different types of \pm nes on the properties of recycled chemical pulp. Journal of Industrial and Engineering Chemistry. 2011;17(1):100-104.

Li Z, Li J, Xu J, Mo LH. Clean bleaching engineering practice for bagasse pulp: totally chlorine-free and elemental chlorine-free bleaching realized with the same production line. Bio Resources. 2015;10(2):2667-80.

Longue Júnior D, Colodette JL, Martino DC. Seção V: Branqueamento de polpas químicas para papel. Branqueamento com peróxido de hidrogênio. In: Colodette JL, Gomes FJB, editores. Branqueamento de polpa celulósica: da produção da polpa marrom ao produto acabado. Viçosa, MG: Universidade Federal de Viçosa; 2015. p.479-506.

Milagres FR, Colodette JL, Rabelo MF, Carvalho DM. Branqueamento de polpa de eucalipto com sequências curtas. Ciência Florestal. 2011;21(1):159-66. 
Milanez AF, Colodette JL, Carvalho AMML. Condições ótimas para branquear polpa kraft de eucalipto com uma seqüência de três estágios. Scientia Forestalis. 2008;36(78):105-13.

Nugroho DDP. Low consistency refining of mixtures of softwood \& hardwood bleached kraft pulp: effects of refining power [dissertation]. Surakarta: School of Environment, Resources and Development, Asian Institute of Technology; 2012.
Technical Association of the Pulp and Paper Industry - TAPPI. Standard methods of technical association of the pulp and paper industry. Atlanta: Technical Divisions and Committees; 2002.

Ventorim G, Caraschi JC, Colodette JL, Gomide JLL. A infuência dos ácidos hexenurônicos no rendimento e na branqueabilidade da polpa kraft. Química Nova. 2009;32(2):373-7.

Revista Árvore. 2018;42(5):e420505 